Economic and Environmental Geology

Review

\title{
A Review on Past Cases of Geophysical Explorations for Assessment of Slope Stability
}

\author{
Ahyun Cho ${ }^{1}$, Inseok Joung ${ }^{1}$, Juyeon Jeong ${ }^{1}$, Seo Young Song ${ }^{1}$, Myung Jin Nam ${ }^{1,2, *}$ \\ ${ }^{1}$ Department of Energy and Mineral Resources Engineering, Sejong University, South Korea \\ ${ }^{2}$ Department of Energy Resources and Geosystems Engineering, Sejong University, South Korea \\ *Corresponding author :nmj1203@gmail.com/nmj1203@sejong.ac.kr
}

\section{ARTICLE INFORMATION}

Manuscript received 30 January 2022

Received in revised form 25 February 2022

Manuscript accepted 26 February 2022

Available online 28 February 2022

DOI : http://dx.doi.org/10.9719/EEG.2022.55.1.111

\author{
Research Highlights \\ - We introduced changes in geophysical properties due to changes \\ in slope properties. \\ - We analyzed on how geophysical surveys were performed on \\ various slopes.
}

\begin{abstract}
Since landslide can cause huge damages to many facilities, close characterization of slopes is needed for appropriate reinforcements for the unstable ones in order to prevent the damages. Geophysical surveys, which can characterize a large area at a relatively low cost without disturbing slopes, have been widely employed for the assessment of slope stability in other countries. However, only conventional direct investigation methods are mainly used in Korea. In this paper, we analyzed various cases, which evaluated slope stabilities by characterizing slopes using geophysical exploration. First, we introduced changes in geophysical properties due to unstable media of slope like fracture location, fracture connectivity and distribution of groundwater level, and subsequently discussed the applicability of geophysical methods to the detection of the changes; the methods include electrical resistivity survey, seismic survey, self-potential survey, induced polarization survey and ground penetrating radar. Based on this description, we analyzed how geophysical surveys were performed on various slopes.
\end{abstract}

Keywords: landslides, slope stability, geophysical exploration, electromagnetic survey, seismic survey

Citation: Cho, A., Joung, I., Jeong, J., Song, S.Y., Nam, M.J. (2022) A Review on Past Cases of Geophysical Explorations for Assessment of Slope Stability. Korea Economic and Environmental Geology, v.55, p.111-125, doi:10.9719/EEG2022.55.1.111.

This is an Open Access article distributed under the terms of the Creative Commons Attribution Non-Commercial License (http:/creativecommons.org/ licenses/by-nc/3.0) which permits unrestricted non-commercial use, distribution, and reproduction in any medium, provided original work is properly cited. pISSN 1225-7281; eISSN 2288-7962/C2022 The KSEEG. Printed by Hanrimwon Publishing Company. All rights reserved. 


\section{해설}

\section{사면 안정성 평가를 위한 물리탐사 적용 사례 분석}

조아현 ${ }^{1} \cdot$ 정인석 ${ }^{1} \cdot$ 정주연 ${ }^{1} \cdot$ 송서영 ${ }^{1} \cdot$ 남명진 ${ }^{1,2, *}$

${ }^{1}$ 세종대학교 에너지자원공학과

세종대학교 지구자원시스템공학과

*책임저자 :nmj1203@gmail.com/nmj1203@sejong.ac.kr

\section{요 약}

산사태가 발생하면 많은 시설에 큰 위험을 초래할 수 있기 때문에, 이를 예방하기 위해 사면의 특성을 상세하게 조사하고 불안 정한 사면에 대해서는 적절히 보강을 수행해야 한다. 물리탐사는 사면을 교란시키지 않고 비교적 저렴한 비용으로 넓은 영역의 특성을 조사할 수 있는 방법으로, 외국에서는 사면의 안정성 조사에 널리 쓰이고 있는 반면 국내에서는 물리탐사 외의 직접적 인 조사 방법들이 주로 쓰이고 있다. 이 논문에서는 물리탐사를 이용하여 사면의 특성을 파악하여 안정성을 평가한 사례들을 분석하고자 한다. 먼저 불안정한 사면물질, 균열 위치 및 연결성, 지하수위 분포에 따른 물성의 변화 등을 알아본 뒤, 이러한 물 성 변화를 파악하기 위해 적용된 물리탐사 기법들인 전기비저항 탐사, 탄성파 탐사를 비롯해 자연전위 탐사, 유도분극 탐사, 지 표투과레이더 탐사 등의 적용법에 대해 알아본다. 이에 기초하여, 기존의 여러 사면에서 실제로 수행되었던 물리탐사 사례들을 분석하였다.

주요어 : 산사태, 사면 안정성, 지구물리탐사, 전기전자탐사, 탄성파 탐사

\section{1. 서 론}

산사태는 거주지, 도로 등 많은 시설에 큰 위험을 초래 하며, 이는 인명피해로 이어지기도 한다(Mandal and Mandal, 2018). 국내의 산사태 피해는 인명피해가 2017 년도에 2명, 2019년에 3명, 2020년 9명으로 꾸준히 발생 하고 있으며, 피해에 따른 복구비용도 2017년도와 2018 년에 각각 2억, 2019년에 약 5억, 2020년에만 약 3조원에 이를 정도로 큰 경제적 손실을 야기하고 있다(index.go.kr). 이러한 산사태를 유발하는 요인은 여러가지가 있으며, 이 는 복잡한 특성을 가지고 있어 사면의 안정성 분석을 위 해서는 사면의 특성을 최대한 상세하게 조사할 필요가 있다(Bogoslovsky and Ogilvy, 1977). 최근에는 짧은 시 간 큰 피해를 입히는 산사태뿐 아니라 오랜 시간 거동하 여 발생하는 땅밀림 산사태에 대한 피해도 발생하고 있 고(Fatahi et al., 2013; Shin et al., 2018), 이에 대한 위험 도 인지가 증가하여 땅밀림에 대한 특성을 파악하고 예 방하고자 하는 연구도 진행되고 있다(Shin et al., 2018).

사면의 특성을 조사하는 데에는 직접적인 방법과 간접 적인 방법이 있다. 시추공 및 노두조사를 통한 불연속면 의 기하학적 속성 및 강도정수 추정 등이 직접적인 방법 에 해당한다. 직접탐사 방법들은 정확도가 높으며 간편 해 가장 대중적으로 수행하고 있으나, 연속적인 정보를 알 수 없으며 시추공의 경우 오히려 사면의 안정성에 영
향을 줄 수 있다는 단점이 있다. 간접적인 조사방법에 속 하는 물리탐사 방법은 비파괴적인 검사로 사면을 교란시 키지 않고 비교적 저렴한 비용으로 넓은 영역을 탐사할 수 있는 방법으로 사면의 안정성 탐사에 널리 쓰이고 있 다(Jongmans and Garambois, 2007). 또한 사면 내의 정 보를 연속적으로 알 수 있다는 장점이 있다.

산사태 분야에서 가장 빈번하게 수행되어온 탐사는 전 기비저항 탐사와 수동형 탄성파 탐사이다. 2007년 이전 의 산사태 분야 물리탐사 적용 관련 논문을 보면 총 23 개의 논문 중 11 개의 논문이 전기비저항 탐사 논문이었 으며, 수동형 탄성파 탐사는 3 개로 전기비저항 탐사에 비해 적은 숫자였다(Jongmans and Garambois, 2007). 2007 년부터 2018년까지의 논문 120 개를 분석하면, 전기비저 항 탐사를 수행한 논문은 총 46개로 두 번째로 많았으며, 수동 탄성파 탐사를 수행한 논문은 총 70 개로 가장 많았 다(Pazzi et al., 2019). 특히 수동 탄성파 탐사 방법은 장 기적인 모니터링이 용이하여 점점 더 많이 수행하는 추 세이다(Pazzi et al., 2019).

전기비저항 탐사는 탐사 방법이 간단해 탐사를 빠르게 수행할 수 있다는 장점이 있어 많은 사면안정 조사 및 분석에 기본적으로 사용하는 탐사 방법이며, 주로 지질 학적 및 수리지질학적 특성(geological and hydrogeological factors)을 파악하는 데 사용한다(Marescot et al., 2008; Pánek et al., 2011; Viero et al., 2015). 또한 전기비저항 
탐사는 사면물질의 특성을 전반적으로 파악할 수 있어 대부분의 사면 조사에서 기본적으로 사용하지만 전기비 저항 탐사는 해상도가 떨어져 암반사면의 균열 및 균열 의 연결성을 파악하기에는 한계가 있으며, 이를 보완하 기 위해 해상도가 높은 탄성파 탐사를 병행하여 탐사를 수행하는 것이 적절하다(Akpan et al., 2015; Deparis et al., 2008). 탄성파 탐사는 사면의 지질 조건과 균열 상태 를 파악하기에 적합한 탐사로, 전기비저항 탐사에 비해 뚜렷하게 높은 해상도를 가지고 있기 때문에 균열의 정 확한 위치와 매질의 경계를 보다 정확하게 파악할 수 있 다는 장점이 있어 사면의 안정성 탐사에 널리 활용하고 있다(Lévy et al., 2010, 2011; Tábořík et al., 2017; Colombero et al., 2016, 2017).

사면 안정성 조사를 위한 물리탐사 적용 시에는 문제 해결에 대한 적합성을 고려해야 한다. 이를 위해서는 탐 사 대상에 대한 지구물리적 대비의 정의 및 이해, 투과
심도 및 해상도와 같은 지구물리학적 방법 특성, 획득 자 료에 대한 지질학적 및 지질공학적 자료를 이용한 보정, 신호 대 잡음비를 고려할 수 있어야 한다(McCann and Foster, 1990). 이러한 점을 고려해 이 논문에서는 지금까 지 산사태 분야에 적용된 물리탐사 연구들을 분석하여 산사태 예방을 위한 물리탐사 적용 연구의 중요성을 논 의하고자 한다.

이 논문에서는 먼저 산사태의 종류와 원인에 대해 알 아본 후, 다양한 물리탐사 방법을 사면안정 조사 및 분 석에 적용하는 방법 및 사례를 소개하고자 한다.

\section{2. 산사태 종류와 발생 요인 별 지구 물리 특성}

\section{1. 산사태 종류와 발생 요인}

산사태의 종류는 가장 대표적인 분류법(Varnes, 1978) 에 따라 사면물질과 붕괴 기작(mechanism)에 의해 나눌

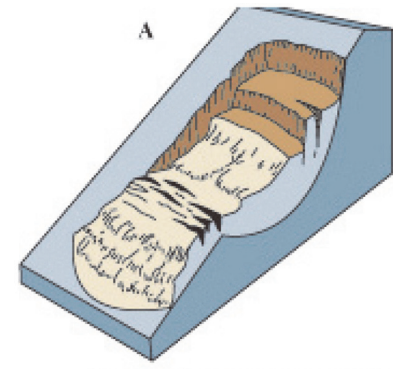

Rotational landslide

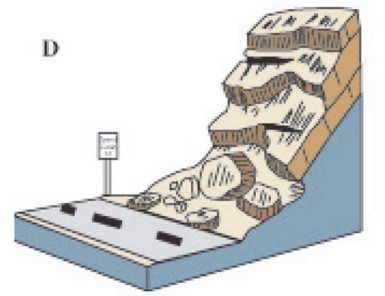

Rockfall

G

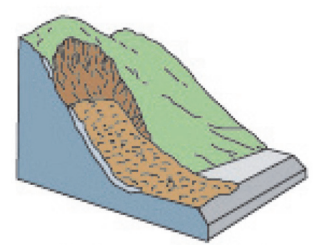

Debris avalanche

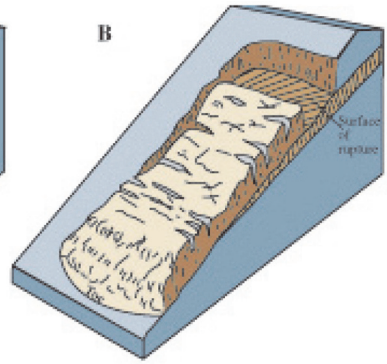

Translational landslide

E

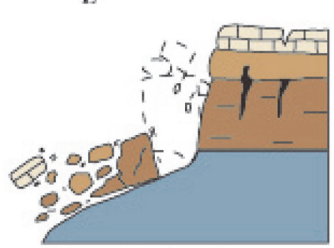

Topple

H

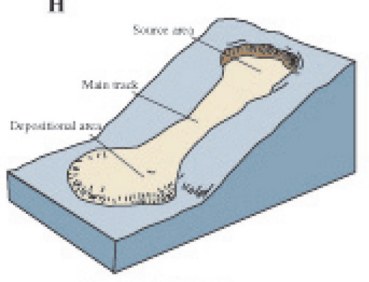

Earthflow

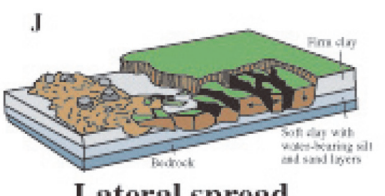

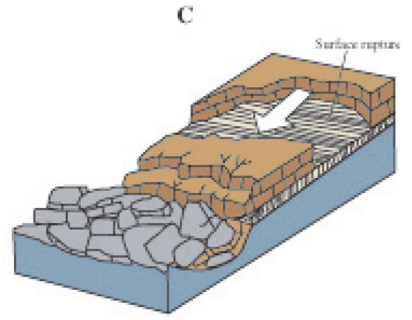

Block slide

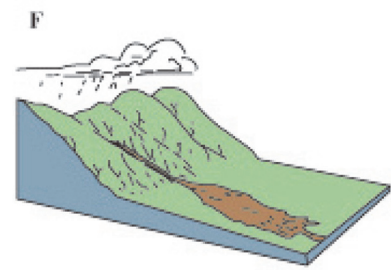

Debris flow

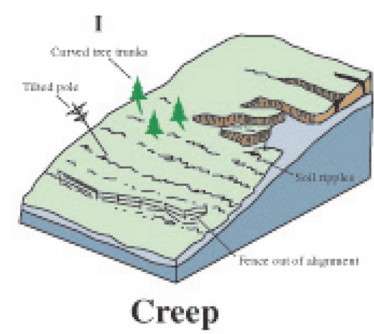

Lateral spread

Fig. 1. Landslide classification based on the type of movement and material (usgs.gov). 
수 있다. 사면물질에 따라 암반(rock), 쇄설물(debris), 토 사(earth)로 나누고, 붕괴 기작에 따라서 붕락(fall), 전도 (topple), 활동(slide), 퍼짐(spread), 흐름(flow) 로 나눈다 (Fig. 1). 산사태 명명법으로는 일반적으로 사면물질을 먼 저 말하고 기작을 붙이며(e.g., Rock fall, Earth fall), 두 가지 이상의 붕괴 기작이 작용하여 일어난 경우 복합 (complex) 산사태라고 한다. 산사태는 사면물질과 붕괴기 작이 아닌 이동속도(rate of movement)에 따라 분류하기 도 하는데, 특히 산사태가 이동하는 속도는 손상의 강도 와 피해를 결정하므로 파악해야 할 중요한 분류 기준으 로 작용한다(Cruz et al., 2018).

산사태의 발생 원인은 크게 내부에서 야기된 경우와 외 부 요인에 의한 것으로 분류할 수 있다. 물리탐사 적용 대상은 주로 내부 요인에 집중하게 되는데, 물리탐사로 확인할 수 있는 내부 요인은 (1) 불안정한 사면물질, (2) 지질학적 구조로 나눌 수 있다. 우선 산사태를 야기하는 불안정한 사면물질은 대표적으로 점토질이 있다. 흡착성 이 큰 점토질은 사면의 안정성을 저해하는 주요 요인 중 하나로 점토 표면에 물이 흡착되어 팽창하며 이로 인해 사면의 강도를 약화시킨다. 구체적으로 크게 3 가지의 경 우로 나누어 볼 수 있는데, 첫번째는 지하수의 흐름에 영 향을 주어 지하수가 급격하게 많이 유입된 다른 층의 안 정성을 저해할 수 있다. 두번째는 해양에서 퇴적되었거 나 다른 요인으로 인해 점토질이 소금 등에 의해 결합되 어 정상적인 구조(Fig. 2(a))가 아닌 하우스 오브 카드 (house of cards) 구조(Fig. 2(c))를 가져 작은 충격이나 물 의 유입에 의해서 무너지게 되는 퀵 클레이(quick clay) 가 되어 안정성을 낮출 수 있다. 세번째는 점토질 자체 가 세립 이질과 자갈로 형성된 플리쉬(flysch) 구조를 가 져 다른 사면물질로 이루어진 층에 비해 안정성이 낮아 지게 된다. 특히 땅밀림 산사태의 경우 점토질 토양에서 는 외부 요인 없이도 발생할 수 있다(Carson and Kirkby, 1972).

지질 구조 역시 산사태의 발생 요인 중 하나로서 암반 층의 방향이나 고결되지 않은 암석 등 약한 층이 있는 경우 산사태가 발생할 수 있으며, 암반 내 균열이 발달 하면 균열 틈으로 지하수가 유입이 되어 암반 블록이 미 끄러질 수 있다. 이에 따라 암반사면 균열의 위치 및 연 결성을 파악하고, 토사면의 경우 급격한 지하수위의 변 동 및 지하수 흐름의 변화 등에 의한 이완영역을 파악하 는 것이 중요하다. 지질 구조에 따른 사면 파괴의 유형 으로는 단층 파쇄대를 따라 파괴되는 활동파괴 및 토질 사면의 불연속면을 따른 파괴와 서로 다른 지층의 경계 부에서 나타나는 지반변형등의 형태로도 구분할 수 있다 (Lee et al., 2007). 균열이 많은 풍화암이 붕괴토로 작용
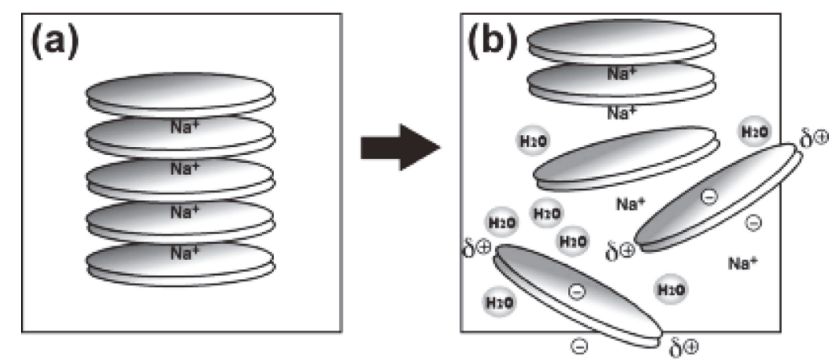

Clay [Hectorite]

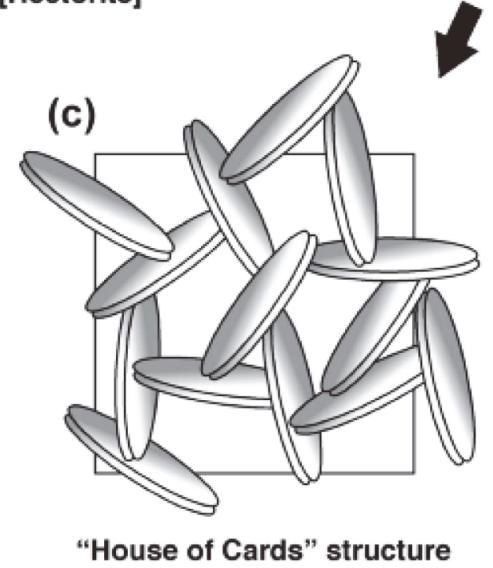

Fig. 2. Schematic representation of the preparation of clay aqueous suspension and the formation of the house-of-cards structure: (a) clay, (b) dispersion (exfoliation) of clay platelets in water, and (c) house-of-cards structure (Haraguchi et al., 2005).

하여 땅밀림 산사태가 발생하기도 한다.

지구물리탐사는 위의 지하 내부 요인들 외에도 외부 요 인인 지하수위의 변화 확인에 매우 유용하게 활용할 수 있다. 물은 지하 매질의 강도를 저하시키는 가장 큰 요 인이며, 집중호우가 많은 우리나라의 경우 다른 요인보 다 이로 인한 산사태가 가장 많이 발생하고 있다(Kim et al., 2009). 지하수는 불안정한 암반 또는 토층의 움직임 을 유발하는 요인이 되며, 안정성이 떨어지는 사면물질 이나 지하 매질의 균열 또는 연약대에 지하수가 증가하 면 사면이 무너질 수 있다. 특히 물은 점토광물과의 상 호작용을 통해 사면의 안정성을 저하시키기도 하고, 암 석 균열 사이에 유입돼 마찰력을 감소시켜 암반사면의 안정성을 저하시킨다. 암석 균열 공극이 물로 포화될 경 우 산사태의 규모가 커지게 된다. 우리나라는 토층의 깊 이가 얕아 강우의 침투로 인한 사면파괴가 많이 발생한 다(Cho, 2018). 집중호우로 인해 지하수가 급격하게 증가 하게 되면 빗물이 암반층까지 내려가지 못하고 토층에 쌓이게 되는데, 이에 따라 파괴면이 토사층과 기반암의 경계를 따라 형성되는 경향이 있다(Cho, 2018). 따라서 집중호우 시의 지하수위 및 지하수의 유동 변화를 파악 하는 것이 중요하다. 반면, 땅밀림은 전단 저항이나 점착 
력이 약한 부분을 따라 토층 전체가 천천히 이동하는 현 상으로 일반적인 산사태와 달리 강우가 없는 경우에도 발생할 수 있다(Stead and Wolter, 2015). 지하수위가 증 가하거나 간극 수압이 상승하게 될 때 토양의 전단력이 감소해 땅밀림이 일어나기도 한다. 지하 수위 증가뿐 아 니라 지하수위 감소에 의해서 발생하기도 하는데 이는 공극수가 빠져나감으로써 공극의 물의 압력에서 토양 입 자로 하중이 전달되는 과정에서 부피 변화가 생겨 발생 한다(Fatahi et al., 2013).

\section{2. 산사태 발생 요인 별 지구물리 특성}

사면 안정성은 토양, 암반, 지하수의 상태 및 특성에 따 라 달라진다(Turner et al., 1996). 토양, 암반의 매질 및 구조에 따라 안정성이 저하될 수 있는데, 매질의 경우 특 히 점토층이 사면의 안정성을 저하시키게 되며, 구조적 으로는 토사면의 경우 연약대가, 암반사면의 경우 균열 대가 사면의 안정성을 저하시키는 원인이 된다. 이러한 내부적인 요인에 의해 안정성이 낮은 사면에 외부적인 요인(trigger)이 결합되면 산사태가 발생하게 된다(Turner et al., 1996). 외부적인 요인으로는 집중호우, 눈의 급속 한 융해, 지하수위의 변동, 화산 폭발, 지진 등이 있으며 (Turner et al., 1996), 국내에서는 주로 집중호우에 따른 지하수위 변동에 의한 산사태가 가장 많이 발생하고 있 다(Kim et al., 2009).

\subsection{1. 불안정한 사면물질}

물을 함유한 점토질은 전기적으로는 $10 \Omega \cdot \mathrm{m}$ 정도의 낮 은 전기비저항을 띄며, 염분이 함유된 퀵 클레이의 경우 $5 \Omega \cdot \mathrm{m}$ 이하로 일반적인 점토보다 낮은 값을 보인다 (Söderblom, 1969). 전기비저항 외에 유도분극(Induced polarization, IP) 탐사는 공극의 내부 면적 및 공극 내 유 체의 물성과 같은 특성을 파악할 수 있으며, 공극 유체 와 입자 사이의 표면에서 발생하는 분극에 의한 충전성 과 같은 변수를 측정하여 점토를 구분할 수 있다(Cardarelli and Filippo, 2009). 점토가 포함되어 있는 층은 상대적으 로 IP 반응이 크게 나타나 탐사 시 고충전성대가 나타나 는 곳을 점토층으로 추정이 가능하다(Choi et al., 2008).

탄성파 속도는 구조적으로 다른 층과의 대비를 보이며, 점토질이 물을 많이 흡수하게 되면 부피가 증가하면서 물의 비율이 높아져 다른 층에 비해 속도 값이 작아질 수 있다. 또한 점토질은 이동체(sliding mass) 내 공극 수 압을 증가시켜 부분적 혹은 완전한 액상화를 발생시켜 흐름을 야기하기도 하는데(Mainsant et al., 2012), 이러한 고체에서 액체로의 상태변화는 사면물질의 강도를 급격
하게 감소시키고 이는 전단파(shear wave) 속도를 저하 시킨다.

\subsection{2. 지질학적 구조}

균열대나 연약대의 경우 지하수의 영향에 따라 전기비 저항 값은 서로 다른 양상을 보인다. 균열대나 연약대가 지하수로 포화된 경우 저비저항 값을 가지며, 그렇지 않 은 경우에는 주변 사면물질과 비슷한 전기비저항 값을 보인다. 반면 탄성파 속도의 경우 지하수의 존재 여부와 관계없이 균열대나 연약대 위치에서는 저속도대로 나타 나게 된다.

한국에서는 토층과 암반층의 경계에 비가 침투하여 안 정성이 저하되어 발생하는 산사태가 가장 빈번하게 일어 난다. 따라서 토층의 심도를 확인하는 것이 중요한데, 일 반적으로 암반층은 고비저항, 높은 탄성파 속도를 보이 며 반대로 토층은 비교적 저비저항, 낮은 탄성파 속도를 가진다.

지질 구조에 대한 탐사 수행 시 가장 많이 수행되는 탐 사는 탄성파 탐사와 지표투과레이더(ground penetrating radar; GPR) 탐사이다. 이 탐사방법들은 해상도가 높아 균열이나 지층 구분이 용이하며, 위치 또한 정확하게 파 악할 수 있다.

\subsection{3. 지하수위의 변화 및 지하수의 유동}

지하수는 전기전도도가 높으며, 이온 함량이 많아 지 하의 전기적 특성을 크게 변화시킨다. 따라서 일반적으 로 지하수 관련 탐사의 경우 탄성파 탐사보다 전기전자 탐사를 주로 사용하게 된다. Archie (1942) 식에 근거하 여 지하의 수포화도가 증가할수록 보다 전기비저항 값은 보다 건조한 매질에 비하여 일반적으로 낮아진다. 또한 지하수 흐름에 의해 자연 전위가 발생하는데(Chambers et al., 2011), 지하의 다공질 매질에서 매질 표면의 전기 이중층에 의해 유체가 흐를 때 음의 이온이 상대적으로 많이 이동하면서 발생하는 자연 전위를 흐름 전위라 한 다(Song and Nam, 2018). 흐름 전위는 기준 전극의 위치 와 유체 흐름의 방향에 따라 이상대의 부호가 다른데, 지 하수의 상향 흐름이 발달된 곳에서는 양의 이상, 하향 흐 름이 주된 곳에서는 음의 이상이 나타난다. 이에 따라 전 단면 혹은 절리를 따라 흐르는 지하수 흐름 방향 혹은 지질 특성에 따른 자연 전위 변화를 측정하여 산사태 영 역을 평가할 수 있다(Bruno and Martillier, 2000; Perrone et al., 2004).

한편 유전율의 경우 약 81 로 높은 값을 가지게 되어 전 자기파가 감쇠되어 GPR 탐사는 적용에 어려움이 있으나, 
불포화 토양과 같은 다른 매질에 비해 큰 값으로 나타나 층 사이의 유전율 대비가 커 천부 지하수위 탐사에 효과 적이다(Schmugge, 1980).

탄성파 속도의 경우 지하수 유입 이전의 균열 혹은 공 극을 채우고 있던 매질의 종류에 따라 값이 달라지게 된다.

\section{3. 산사태 예방을 위한 물리탐사의 적용}

산사태 분야에서 물리탐사는 사면의 붕괴 형태보다 사 면을 구성하는 사면물질의 종류와 물성, 상태 및 시간에 따른 변화, 지하수위 및 지하수의 시간에 따른 변화, 사 면의 변위에 대한 정보를 파악하기 위해 적용된다(Pazzi et al., 2019). 다양한 전기전자 탐사법들과 탄성파 탐사 법들이 적용되었으며 특히 전기비저항 탐사와 수동 탄성 파 탐사가 많이 수행되었다. 이 장에서는 산사태에 적용 된 여러 물리탐사 방법을 소개하였다.

\section{1. 탄성파 탐사}

탄성파 탐사는 물리탐사 방법 중 해상도가 높고 가탐 심도가 깊어 석유 저류층 탐사, 지질 구조 탐사 등 많은 분야에 사용하고 있는 탐사법으로 사면안정 조사 및 분 석에도 가장 많이 이용하는 탐사법이다(Pazzi et al., 2019). 탄성파 탐사는 송신원의 종류에 따라 능동형 송신원을 사용하는 탐사와 수동 송신원을 사용하는 탐사로 나눌 수 있다. 능동형 탄성파는 해상도가 높은 것이 가장 큰 장점인 탐사법으로 반사법 탐사와 굴절법 탐사, 탄성파 토모그래피 탐사가 있다. 이 중 토모그래피 탐사가 일반 적으로 균열의 위치를 확인하기에 더 용이하기 때문에 균열의 정확한 위치를 파악하기 위해 주로 수행하며, 지 하구조 내의 균열 및 지층구조를 보기 위해 반사법 탐사 와 굴절법 탐사를 수행한다.

수동 탄성파 탐사는 최근 사면안정 조사 및 분석을 수 행할 때 가장 많이 사용하고 있는 탐사법으로 송신원이 필요하지 않아 불안정한 사면에서 탐사를 수행하기에 적 합한 탐사방법이다. 수동 탄성파 탐사는 토사면보다는 암 반사면에서 더 많이 사용한다. 이는 암반사면에서 발달 한 절리에 의해 암석 블록이 움직이며 발생하는 진동을 분석하는데 수동 탄성파 탐사법이 더 효과적이기 때문이 다. 이처럼 수동 탄성파 탐사는 암반 블록의 거동을 확 인하는데 주로 사용하며, 장기간 모니터링에 적합하여 사 면의 안정성 해석에도 많이 사용되고 있다(Lévy et al., 2010; Lévy et al., 2011; Manconi et al., 2016; Colombero et al., 2016; Colombero et al., 2017). 이 외에도 탄성파 모니터링을 수행하기도 하는데 이 경우 자연 발생 송신 원과 암반 사면의 움직임에 의한 진동을 식별해야 하며,
이는 국지 규모(local magnitudes; ML)와 지속 규모(duration magnitudes) (MD) 간의 비율을 이용하여 구분할 수 있다. 낙석과 관련된 신호는 $\mathrm{ML} / \mathrm{MD}<0.8$ 인 반면, 자연 지 진의 경우 $\mathrm{ML} / \mathrm{MD}$ 가 약 1 의 값을 가진다(Manconi et al., 2016).

사면에서의 탄성파 탐사는 주로 지층의 깊이와 형상, 단층 파쇄대의 위치 등 지질 경계면 및 연약대의 위치를 확인하고자 한다. 암반의 탄성파 속도는 암반의 강성을 나타내는 풍화정도와 균열의 빈도(RQD)와 밀접한 관계 가 있기 때문에 암반평가에 널리 이용되고 있다. 암반을 구성하고 있는 암석이 견고하고 강성이 높더라도 균열이 많으면 강성이 낮아지고 균열이 없는 암석(intact rock)에 비해 상대적인 저속도대(low velocity zone)가 나타난다. 점토질이 많은 사면의 경우 sliding mass 내 공극수압이 증가하면서 부분적 혹은 완전한 액상화가 발생해 흐름이 발생하게 되는데(Mainsant et al., 2012), 이 상태변화는 매질의 강성을 급격하게 감소시키고 이는 전단파의 속도 저하를 발생시키므로 탄성파 탐사를 통해 확인할 수 있 다. 사면에서 능동 탄성파 탐사를 수행할 때는 다이너마 이트 등의 송신원이 땅의 안정성을 저하시킬 수 있으므 로 주로 슬렛지 해머를 사용한다.

\section{2. 전기비저항 탐사}

전기비저항 탐사는 물리탐사를 이용한 사면 안정성 조 사에서 전기전자탐사 중 가장 많이 사용하는 탐사 방법 이다. 퀵 클레이 탐사와 지하수 유동에 대한 탐사 수행 시 많이 이용하며, 암반사면에서는 전극 설치가 어려우 므로 토사사면에서 더 많이 이용한다. 또한 단일 시간에 서만 탐사를 수행하기도 하나, 변화를 관측하는 것이 중 요한 산사태의 특성상 전극을 설치해둔 뒤 지속적으로 모니터링을 수행하는 경우도 늘어나고 있다(Palis et al., 2017; Travelletti et al., 2010). 전기비저항 탐사의 비교적 낮은 해상도를 보완하기 위해 탄성파 탐사 등 다른 탐사 방법과 함께 탐사를 수행해 해석의 신뢰도를 높인다(레 퍼런스 추가). 탐사의 편의상 종종 IP 탐사와 함께 수행 하기도 한다(Bortolozo et al., 2019; Dahlin et al., 2013; Marescot et al., 2008).

사면 조사에서 조사하고자 하는 사면의 깊이와 그에 맞 는 탐사법을 적용해야 하는데, 전기비저항 탐사는 전극 배열 방법에 따라 가탐심도 및 해상도를 조정한다. 사면 조사에서 가장 많이 사용되는 전극 배열법은 쌍극자 배 열(dipole-dipole array)과 웨너 배열(Wenner array)이다. 쌍극자 배열은 수평 탐사에 대한 민감도가 높으며, 웨너 배열은 수직 분해능이 높은 배열이다. 대체적으로 두 배 열 중 한 배열만을 사용하나, 때에 따라서 때에 따라 두 
배열을 함께 사용하는 경우도 있다. 넓은 영역을 탐사해 야 하기 때문에 측선은 대부분 $100 \mathrm{~m}$ 이상 설치하게 된다.

\subsection{GPR 탐사}

GPR 탐사는 토사사면보다는 암반사면에서 많이 사용 하는 물리탐사 방법으로, 가탐심도의 한계가 있으나 균 열의 위치 및 연결성을 자세하게 알 수 있다는 장점이 있으며 탐사 장비가 크지 않아 이동이 불편한 가파른 사 면에서도 사용할 수 있다. 토사면의 경우 식물의 뿌리에 의한 잡음이 커 적합하지 않으나(Sass et al., 2007; Sass et al., 2008) 건조한 암반사면에서 적용이 용이하다. GPR 탐사로 구조적인 반사면을 확인하기도 하지만, 반사된 파 의 Amplitude에 따라 파쇄대를 확인하기도 한다(Roch, 2006).

\subsection{IP 탐사}

IP 탐사는 충전성을 가지고 있는 매질을 구분하는 데 적합한 탐사방법으로, 특히 점토질에 대한 민감도가 높 아 점토질 탐사에 많이 사용하고 있다. 측정 방법에 따 라 직류 전류 송신원을 이용하는 시간영역 IP, 교류 전류 송신원을 이용하는 진동수 영역 IP, SIP 및 복소전기비저 항 탐사로 나뉘지만(Kim et al., 2017), 산사태 영역에서 는 주로 시간영역 IP 탐사를 사용하였다.

IP 탐사는 전기비저항 탐사와 측선을 공유할 수 있어 전기비저항 탐사와의 복합 탐사가 용이하다는 장점이 있 으며, 전기비저항 탐사의 한계점을 보완할 수 있어 주로 전기비저항 탐사와 함께 적용한다. 점토질의 경우 전기 비저항 탐사만 수행하게 되면 지하수와 점토질이 모두 저비저항대로 나타나 구분이 어려우나, IP 탐사를 통해 얻을 수 있는 정규화된 충전율 값이 다른 영역에 비해 확연하게 높은 값을 가져 지하수와 구분할 수 있다(Dahlin et al., 2013).

\subsection{SP 탐사}

산사태 분야에서의 $\mathrm{SP}$ 는 이동체(landslide body) 내의 유체 거동 및 산사태 경계에서의 유체 흐름 변화로부터 산사태 위험성 분포를 해석한다. 이 때 $\mathrm{SP}$ 는 지하수 흐 름에 의한 전위인 흐름 전위(streaming potential)에 기초 한다. 측정 자료는 $\mathrm{SP}$ 를 탐사 영역에 걸쳐 영상화하여 지 하수의 흐름을 해석한다(Gex, 1990; Gex, 1993). 측정 전 위를 영상화하여 탐사 영역 내의 SP 신호를 정성적으로 해석하는 방법 외에 교차상관(cross-correlation) 알고리듬 (SP tomography, SPT) (Patella, 1997 a,b, 1998)을 활용하 여 지하수 흐름에 의해 전류가 축적된 지역을 음 또는 양의 전하가 발생할 확률로 해석할 수 있다(Perrone et al., 2004; Chambers et al., 2011). 해당 방법은 화산지역 과 산사태 영역에서 효과적으로 적용되었다(Patella 1997b, Lapenna et al., 2003; Perrone et al., 2004; Chambers et al., 2011).

$\mathrm{SP}$ 신호는 지하수 흐름에 의해 발생하므로 건기에는 신호가 약하게 나타난다(Naudet et al., 2008). 산사태 내 부 영역에서는 지하수의 침투(infiltration)가 발달하여 대 체로 음의 SP 이상이 나타난다(Perrone et al., 2004; Naudet et al., 2008; Santoso et al., 2019; Sujitapan et al., 2019). $\mathrm{SP}$ 신호는 수두 기울기 방향과 반대로 전위 기울기가 나 타나므로(Song et al., 2021), 지하수의 상향 흐름이 발달 한 곳에서는 양의 이상이 나타나며 지하수가 사면의 상 부에서 하부로 이동할 때는 음의 이상대가 나타난다. SP 신호 세기는 산사태의 지질 특성에 따라 상이하게 나타 난다(Naudet et al., 2008).

$\mathrm{SP}$ 탐사 수행시에는 보통 전기비저항 탐사와 함께 수 행한다. 사면안정 조사 및 분석에서 SP 탐사는 넓은 영 역을 대상으로 하므로 루프(loop) 형태와 일반적인 전기 비저항 탐사와 동일하게 한방향으로 연속한 형태로 비분 극 전극을 설치하여 탐사를 수행한다. 배열법은 주로 그 래디언트(gradient) 배열 혹은 복합 배열 방법을 활용하 였다(Perrone et al., 2004; Naudet et al., 2008).

\section{4. 물리탐사 적용 사례}

산사태 영역에서의 물리탐사 적용 사례는 크게 사면 특 성화를 위한 단일 시간대 탐사와 사면의 변동을 확인해 점진적으로 변화하는 사면의 안정성을 모니터링 할 수 있는 시간 경과 모니터링으로 나눌 수 있다. 사면 특성 화를 위한 탐사는 주로 내부 요인을 확인해 안정성이 낮 은 영역을 파악하며, 시간 경과 모니터링은 사면을 주기 적으로 관찰해 산사태 발생 이전에 산사태 경보에 도움 이 되는 정보를 제공한다.

\section{1. 사면 특성화를 위한 탐사}

4.1.1. 불안정한 사면물질(점토질 분포)

점토질의 가장 큰 특징은 낮은 전기비저항 값을 가진다 는 점이며, 따라서 전반적으로 전기비저항 탐사를 기초로 하여 탐사를 수행한다. 그 중에서도 퀵 클레이는 $5 \Omega \cdot \mathrm{m}$ 이하의 값을 가져 다른 점토질과도 구분할 수 있다 (Söderblom, 1969). Dahlin et al. (2013) 과 Akpan et al. (2015) 는 이러한 특성을 바탕으로 점토질을 포함한 사 면에 대한 탐사를 수행하였다. 일반적으로 전기비저항 탐 사보다 IP 탐사가 점토질에 더 민감하게 반응하는데, 스 웨덴의 Fråstad 지역에서 퀵 클레이의 분포를 확인하기 


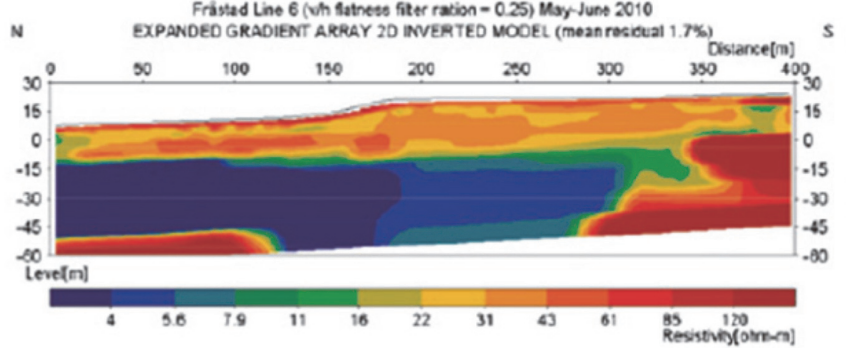

(a)

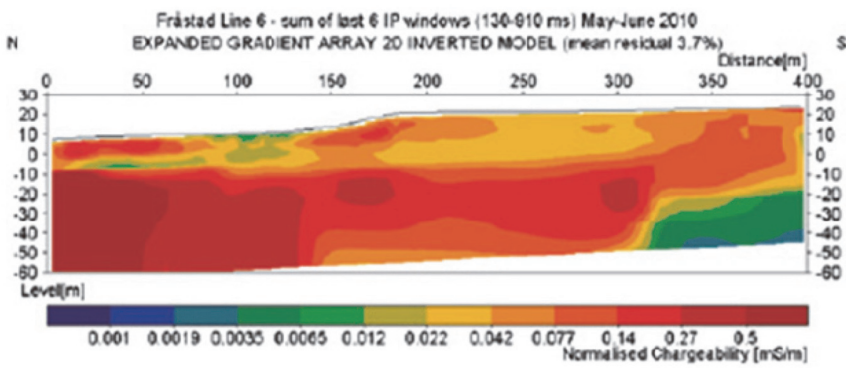

(b)

Fig. 3. Resistivity section (a) and normalized chargeability section (b) for Line 6 based on L1-norm (robust) inversion (Dahlin et al., 2013).

위해서 전기비저항 탐사뿐 아니라 TDIP 탐사를 수행한 결과(Dahlin et al., 2013), 이 지역의 Gota 강과 가까운 곳의 깊은 부분에서 $10 \Omega \cdot \mathrm{m}$ 이하의 매우 낮은 전기비저 항 값을 가지는 영역이 확인되었고(Fig. 3(a)), 지하수의 영향에 의해 점토질이 실제 존재하는 지역에 비해 저비 저항이 더 넓은 지역에서 관찰되었다. TDIP 탐사 분석 결과 저비저항 영역 중에서도 퀵 클레이가 존재하는 영 역은 0.077 이상의 높은 정규화된 충전율 값으로 나타나 퀵 클레이 구역을 IP 탐사를 통해 더 세밀하게 특성화하
였다(Fig. 3(b)).

점토질이 다른 사면물질 사이에 위치하게 되면 집중호 우시 물을 가두어 사면의 강도를 저하시키게 되는데, 셰 일 층과 이회토 층이 번갈아 나타나게 되면 점토질이 깊 은 층으로의 물의 침투를 막아 침투하는 지하수가 셰일 층과 이회토 층의 경계면에 축적되어 산사태를 유발할 수 있다. 나이지리아의 Obot Ekpo의 산사태가 발생한 지 역에서 전기비저항 및 탄성파 굴절법 탐사를 수행한 결 과(Akpan et al., 2015), 탄성파 굴절법 탐사 결과 산사태

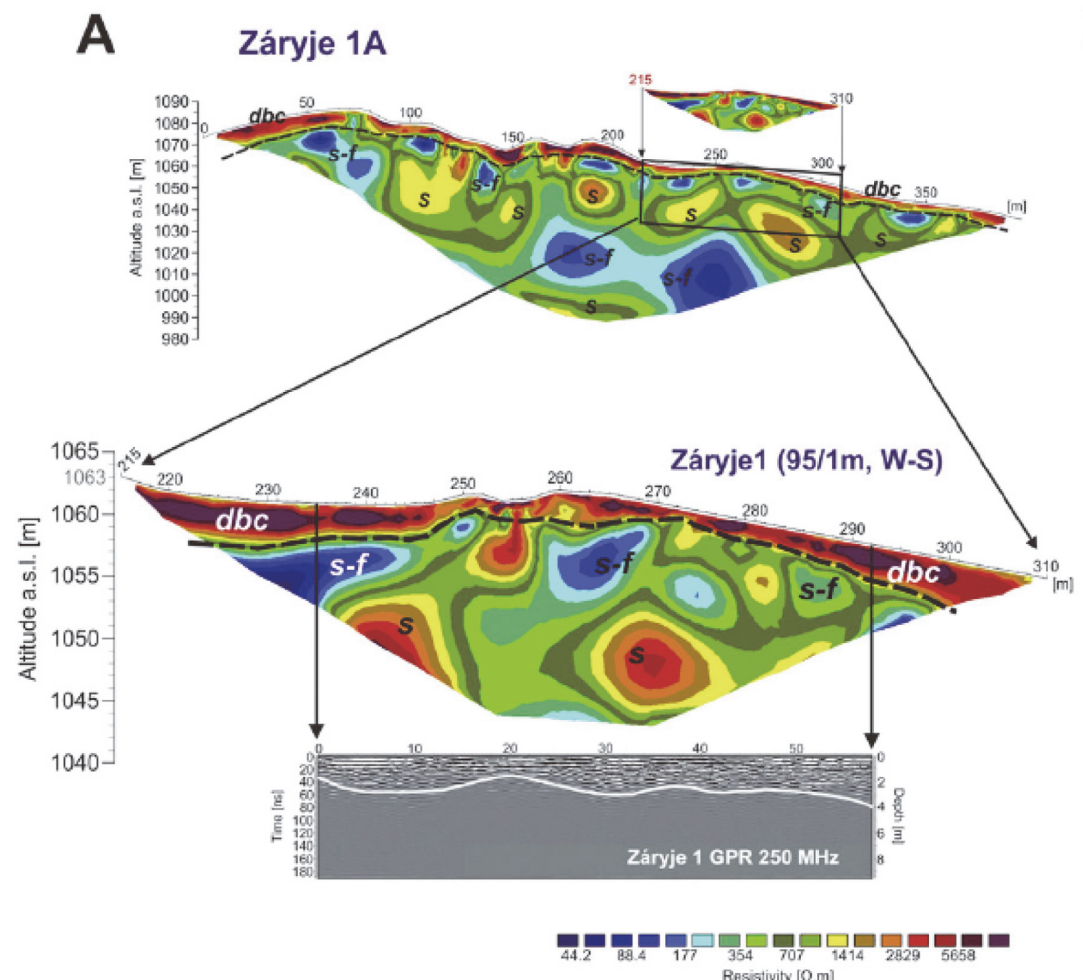

B
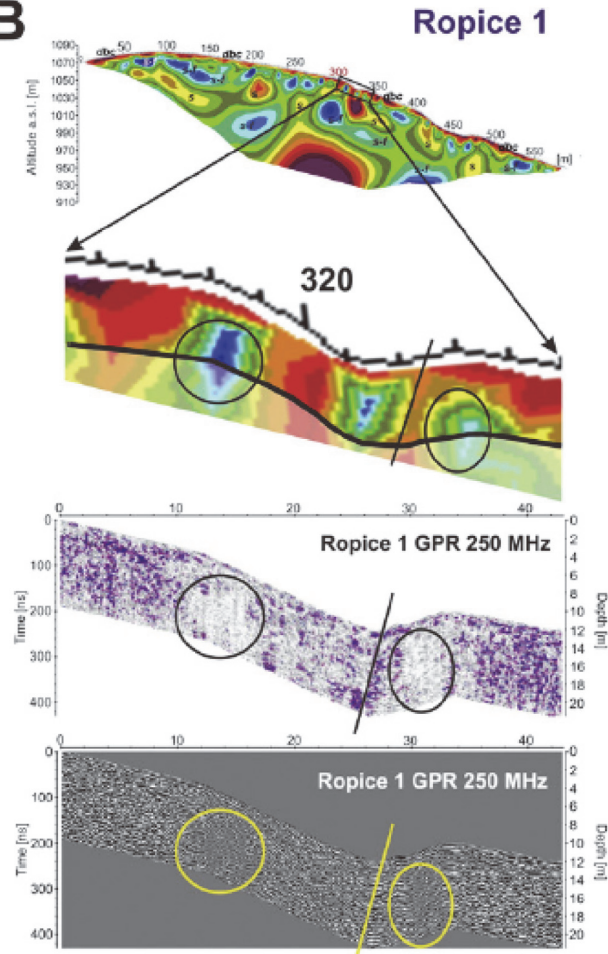

Fig. 4. GPR results compared to ERT pseudosections: (A)Záryje site - GPR revealed thickness of colluvial mantle and surface of the underlying flysch bedrock; (B) Ropice - strong signal attenuation zones in the GPR profile is in agreement with low resistive zones in ERT section (Táboř́k et al., 2017). 
가 발생하지 않은 영역의 평균 $\mathrm{P}$ 파 속도는 $1820 \mathrm{~m} / \mathrm{s}$ 의 빠른 값을, 산사태가 발생한 영역에서는 $655 \mathrm{~m} / \mathrm{s}$ 의 느 린 속도를 보였다. 또한 전기비저항 탐사에서 저비저항 의 셰일 층 $(\rho<10 \Omega \cdot \mathrm{m})$ 과 비교적 높은 전기비저항 값 을 가진 이회토 $(\rho>10 \Omega \cdot \mathrm{m})$ 가 번갈아가며 나타나는 층 서 구조를 확인하였다.

플리쉬 구조의 경우 점토질과 자갈이 번갈아 나타나는 구조로 다른 점토층에 비해서는 더 높은 값을 가지는 편 이나, 다른 층에 비해서는 낮은 전기비저항 구조를 가진 다. 따라서 전기비저항 외에도 다른 탐사를 복합적으로 수행하여 점토층에 의해 나타나는 기반암의 불연속성을 파악하는 것이 좋다(Táboŕík et al., 2017). 특히, 전기비 저항 탐사를 위주로 하여 GPR 탐사, 탄성파 굴절법 탐 사, 중력탐사를 통해 자료의 신뢰성을 더하였다. 체코의 Záryje 지역 전기비저항 탐사 결과 표토층은 $3000 \Omega \cdot \mathrm{m}$ 이상의 고비저항대로 관측되며, 두께는 2-10 m 로 확인 할 수 있다. 긴 측선(Záryje1A)의 $100-170 \mathrm{~m}$ 구간과 Záryje1 profile 구간에서 명확한 붕괴의 흔적을 확인할 수 있으며, Záryje1 탐사 결과(Fig. 4A) 표토층 아래로 저 비저항대 $(<300 \Omega \cdot \mathrm{m})$ 와 비교적 고비저항대(800-3000 $\Omega \cdot \mathrm{m})$ 로 나타나는 구조가 번갈아서 나타나며, 이는 플리쉬 구 조로 확인하였다.

\subsection{2. 지질 구조 파악}

- 균열 위치 및 연결성 확인

사면은 크게 암반사면과 토사면으로 나눌 수 있으며, 암반사면의 경우 균열의 구조가 사면의 안정성에 큰 영 향을 미치기 때문에 균열의 연결성을 확인하기 위해서 탄성파 탐사를 위주로 수행한다. 균열의 구조를 파악하 는 데에는 지표 탐사보다 시추공 탐사가 더 효과적이나, 사면의 안정성에 영향을 끼칠 수도 있기 때문에 지표에 서만 탐사를 수행하기도 한다.

암반사면의 균열의 구조 및 연결성을 파악하기 위한 탐 사로 가장 자주 쓰이는 탐사는 탄성파 굴절법 탐사와 탄 성파 잡음 모니터링이다. 이 두 탐사는 같이 수행하는 경 우가 많은데, 먼저 해상도가 높은 탄성파 굴절법 탐사를 통해 기존에 존재하는 균열의 위치 및 연결성을 파악한 후 탄성파 잡음 모니터링을 통해 이후 균열 및 암반 블록 의 움직임을 확인한다(Colombero et al., 2016; Colombero et al., 2017; Lévy et al., 2010). Colombero et al. (2016) 과 Colombero et al. (2017)은 세 개의 시추공과 지표 측 선을 이용하여 이탈리아의 Madonna del Sasso 사면의 안 정성 검토를 위해 탄성파 굴절법 탐사를 수행한 후 향후 사면의 모니터링을 위한 탄성파 배경잡음(seismic noise) 탐사를 수행하였다. 해당 연구지역은 매우 가파른 절벽
이며, 이에 따라 직접적인 접근과 모니터링이 어려워 물 리탐사를 수행하여 사면의 안정성 조사를 하고자 하였다. 굴절법 탐사를 통해 균열의 위치 및 방향을 확인하고자 하였다. 이 결과 균열에 가까울 때 트레이스(trace)의 지 속시간(duration)이 증가하고 비균질매질 및 균열이 있는 매질에서는 산란이 발생하여 고주파의 $\mathrm{P}$ 파만 남는 양상 을 보였다. 이를 바탕으로 균열의 위치를 추정하였으며, 불안정한 사면의 동적 거동에 대한 이해를 위하여 탄성 파 배경잡음 탐사를 수행하였다. 탄성파 배경잡음 탐사 는 동일한 모니터링 기간 내에 측정한 탄성파 신호의 스 펙트럼을 분석하였으며, 이 분석 결과 공통된 최초의 3 개의 공진주파수를 확인하였고, 이 신호는 각 수신기에 가장 가까운 균열에 의해 진동방향이 제어된 결과를 보 였다. 또한 불안정한 영역 사이에서는 강한 변동성을 가 졌다(Fig. 5). 이를 통해 확인한 균열의 위치는 직접적인 시추조사 및 외부에서 보이는 균열의 위치와 일치함을 확인하였으며, 향후 새로 균열이 발생하는 것을 확인하 기 위한 탄성파 배경잡음 탐사 또한 접근이 어려운 절벽 등지에서 유용할 것으로 보인다.

전기비저항 탐사 또한 대략적인 균열의 위치를 파악하 기 위해서 사용하기도 하는데, 이경우 주로 전기비저항 탐사의 해상도가 낮다는 단점을 보완하기 위해 해상도가 높은 탄성파 탐사나 GPR 탐사를 병행하게 된다(Sass et al., 2006; Heincke et al., 2010). Heincke et al. (2010)이 노르웨이 서쪽에서 발생한 Åknes 산사태 지역에서 전기 비저항 탐사와 탄성파 토모그래피를 수행한 결과, 저속 도층 이상대 $(<1400 \mathrm{~m} / \mathrm{s})$ 와 저비저항 이상대 $(<13 \mathrm{k} \Omega-\mathrm{m})$ 가 비슷한 구간에 존재하는 것을 파악하였고, 이는 인장파 괴를 통해 생긴 균열대에 물이 유입되며 나타난 저속도, 저비저항 이상대로 해석하였다(Heincke et al., 2010).

Sass et al.(2006)은 절벽을 따라 전형적으로 산사태가 발생한 Öschingen 산 사면에서 시추와 2D ERT, GPR을 이용한 탐사를 통해 사면의 안정성 평가를 수행하였다. 먼저 GPR 은 진동수에 따라 가탐심도가 달라지므로 심 도 $4 \mathrm{~m}(100 \mathrm{MHz}), 6 \sim 8 \mathrm{~m}(50 \mathrm{MHz})$, 그리고 $8 \sim 13 \mathrm{~m}$ $(25 \mathrm{MHz})$ 세 경우의 탐사를 진행하였다. 지표 아래의 고 비저항 영역에서 가장 좋은 결과를 취득할 수 있었으며, 전도성이 높은 colluvium 영역에서는 강한 감쇠가 발생 하여 자료를 사용할 수 없었다. 게다가 $10 \mathrm{~m}$ 보다 깊은 심도의 경우 나무로 인해 발생한 잡음으로 어려움이 있 었다. 하지만 산사태의 지하구조에 대한 정보는 획득할 수 있었으며 산사태 활동면이 교차 측선의 일부에서 표 면과 평행한 반사 형태로 나타난다는 것을 바탕으로 교 차 측선에서 확인한 기반암의 위치 및 $\mathrm{ERT}$ 데이터를 검 증하는 데는 뒷받침할 수 있다. 


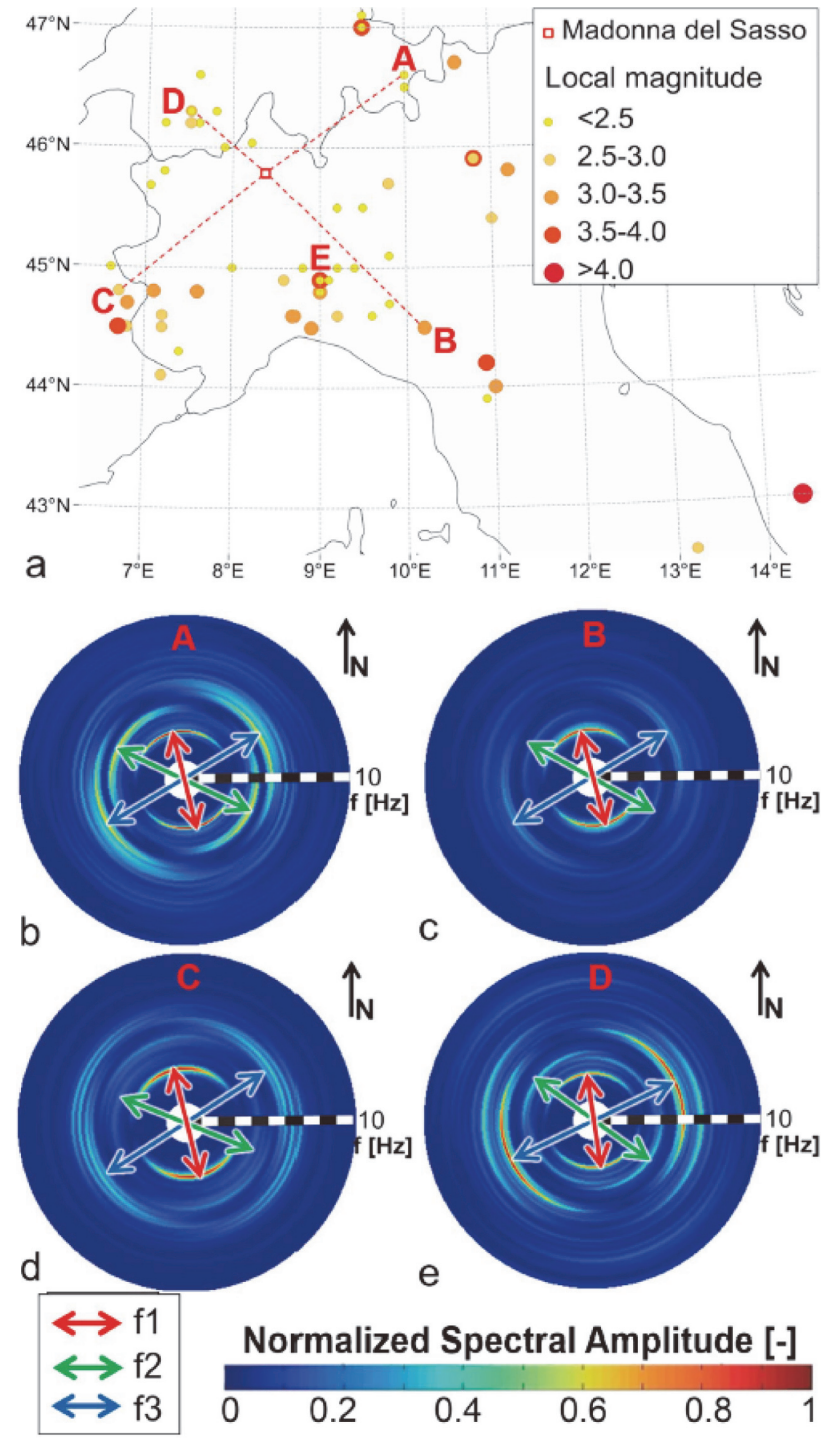

Fig. 5. (a) Epicentral location map of 65 earthquakes recorded at the test site. A-D: selection of four events with almost perpendicular azimuthal directions from Madonna del Sasso. Horizontal spectral polar plots (radius = frequency, $0-10 \mathrm{~Hz}$ ) at S7 for (b) event A, (c) event B, (d) event C, and (e) event D. Polar plots are plotted in the same color scale, with spectral amplitude normalized to $\mathrm{fl}$ spectral value at S7. In each plot, frequency values and related vibration directions are highlighted in red for $\mathrm{fl}$, in green for $\mathrm{f} 2$, and in red for $\mathrm{f} 3$ (Colombero et al., 2017).

GPR 탐사는 해상도가 높아 단독으로 탐사를 수행하여 균열대가 존재하는 영역의 진폭 반사(amplitude reflectivity) 가 더 큰 값을 보여 균열의 위치를 정확하게 파악할 수 있었다(Roch et al., 2006). 그러나 GPR 탐사 시, 사면 암 석 표면의 울퉁불퉁함이나 식생 등에 의한 영향으로 잡 음이 많이 발생하기 때문에 AGC (windowlength $100 \mathrm{~ns}$ ), 밴드패스 필터(bandpass filter), 최소 위상 곱풀기(minimum phase deconvolution), f-k 필터 등을 통해 잡음을 제거한 후 자료를 해석하였다. Roch et al. (2006) 은 $30 \sim 100 \mathrm{~ns}$ 의 시간 범위 내에서 각 트레이스에 대한 평균 진폭을 계산해 약 $1.5 \sim 5 \mathrm{~m}$ 깊이에서의 균열의 분포를 파악하였다.

\section{- 지하수의 분포}

토양의 함수비 및 수문학적 모델을 구성하는 경우도 있 는데, 이 경우 활동면(slip surface)을 파악하게 될 수 있 다. 집중호우시에 사면에서 무너질 가능성이 있는 구간 을 파악하는 것이 목적으로, 사면의 $3 \mathrm{D}$ 지질모델을 구성 하는 경우도 있다(Maio et al., 2020). 사면의 수문학적 $3 \mathrm{D}$ 지질모델을 구성하게 되면 산사태 조기경보 시스템 을 구성할 수 있으며, 이 경우 전기비저항 탐사가 유용 하게 사용된다(Maio et al., 2020).

활동면은 강우 시 마찰력의 저하 및 유효응력의 저하 로 인해 사면이 미끄러질 가능성이 있는 면으로, 대개 토 층심도와 관련이 있다. 토사면의 경우 주로 기반암과 토 층의 경계에서 물이 유입되어 마찰력이 저하되면서 산사 태가 발생하게 된다. 집중호우 시에 발생하는 산사태의 경우 대부분 이로 인한 산사태이며, 그 규모가 암반사면 산사태에 비해 광범위하기 때문에 토층 심도를 확인하는 것이 토사면 안정성 평가에서 매우 중요하게 된다. 토사 면과 암반사면은 물성의 대비가 명확하기 때문에 전기비 저항, GPR, 탄성파 탐사를 전반적으로 사용할 수 있으나, 비용적인 측면에서 전기전자탐사가 비교적 저렴하기 때 문에 전기전자탐사를 위주로 탐사를 수행한다.

전기비저항 탐사를 수행하는 경우 건조한 토양과 지하 수가 포함된 토양, 그리고 암반사면의 전기비저항 값의 구간을 나누어 파악하며, 이동면을 구분하고 이 중 함수 비가 높은 영역을 다시 구분하면 산사태의 위험성을 판 단할 수 있다(Kamiński et al., 2021). 즉, 함수비가 높은 점토암 구역이 저비저항 영역으로 나타났으며, 이를 고 위험 지역으로 구분한다. 파나마 운하의 Isthmus에서 탐 사를 수행한 결과, 점토질과 지하수가 같이 있는 경우 약 4 $\sim 40 \mathrm{ohm}-\mathrm{m}$, 점토질 토양만 있을 때는 약 $40 \sim 130 \mathrm{ohm}-\mathrm{m}$, 암석은 대체로 그 이상의 전기비저항 값을 보였고, 이를 통해 약 5 10 m 의 얕은 토층 심도를 확인하였다(Mojica et al., 2013). 또한 Altındag 산사태 지역에서 토층 심도 를 확인하기 위한 전기비저항 탐사 및 탄성파 굴절법 탐 사를 수행한 경우, 토층의 전기비저항은 $100 \Omega \cdot \mathrm{m}$ 이하, $\mathrm{P}$ 파 속도는 $2000 \mathrm{~m} / \mathrm{s}$ 이하로 나타났다(Göktürkler et al., 2008).

수동 탄성파 탐사는 송신원을 이용하는 탄성파 탐사에 비해 저렴하여 토층 심도를 파악할 때 사용한다면 유리 할 수 있는데, MASW 탐사뿐만 아니라 탄성파 간섭기법 
Sections longitudinal to landslide axis

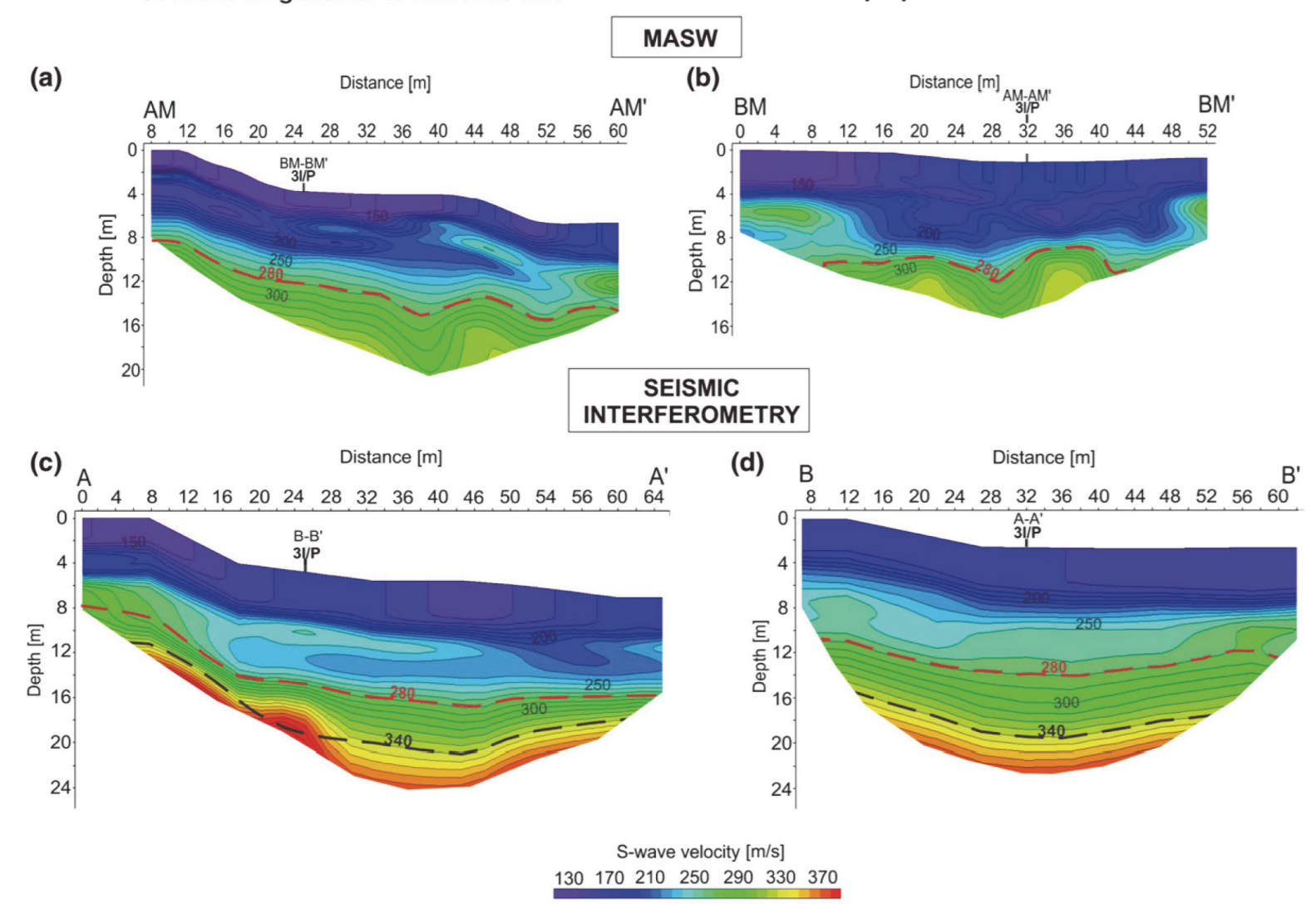

Fig. 6. S-wave velocity sections from MASW-longitudinal (a) and perpendicular (b) to landslide axis and from seismic interferometry with seismic noise-longitudinal (c) and perpendicular (d) gained on Just-Tegoborze landslide. Red thick dashed line indicates interpreted seismic border between clayey colluvium and weathered rock colluvium; black thick dashed line indicates interpreted seismic border between weathered rock colluvium and less weathered flysch bedrock (3I/P denotes borehole/cross point) (Harba et al., 2019).

을 통해 토양층과 기반암을 구분하였다(Harba et al., 2019). 토양층과 기반암의 $\mathrm{P}$ 파 속도 대비는 매우 크게 나타나며, 간섭기법을 이용하여 속도 프로파일 역시 유사한 결과를 보인다(Fig. 6).

최근에는 클러스터링을 수행하여 전기비저항 탐사 결 과와 탄성파 굴절법 탐사 결과에서 산사태 위험 영역을 구분하여 $3 \mathrm{D}$ 결과를 획득하기도 하였다(Zakaria et al., 2021). 이때, 이동체의 역치값을 전기비저항은 $1200 \Omega \cdot \mathrm{m}$ 이하, 탄성파 속도는 $1200 \mathrm{~m} / \mathrm{s}$ 이하로 두었으며, 두 값이 모두 역치값 이하의 값을 가질 때, 한 쪽만 역치값 이하 의 값을 가질 때, 양 쪽 다 역치값을 초과하는 값을 가질 때로 분류하였다. 이 경우 매질에 대한 각 방법의 서로 다른 해상도를 보완할 수 있다.

이러한 물리탐사 방법들은 지하수에 대한 정보를 간접 적으로 파악하게 되지만 SP 탐사는 지하수에 대한 정보 를 가장 직접적으로 파악할 수 있다. 이동체 내의 유체 거동 및 이동체 경계에서의 유체 흐름 변화를 해석하는 데, 점토질이 많이 포함된 산사태에서는 $-14-4 \mathrm{mV}$ 의
SP가 측정되었으며(Perrone et al., 2004), 파쇄된 암반이 많이 포함된 산사태에서는 $-150 \sim 350 \mathrm{mV}$ 의 $\mathrm{SP}$ 가 측정 되었다(Meric et al., 2005). 이는 지하수 흐름의 동적 특 성, 침투 정도, 유체 전기전도도, 높은 비저항의 암석과 관련이 있다(Naudet et al., 2008). 또한 SP 신호는 지형 에 의해서도 영향을 받는데, 자료에서 지형 보정을 수행 하면 침투에 의한 보다 뚜렷한 SP 신호를 관측할 수 있다.

\section{2. 시간 경과 모니터링}

산사태의 위험성은 강우량에 따른 토양 함수비 변화에 의해 실시간으로 변동하게 된다. 이에 따라 모니터링의 중요성이 부각되고 있으며, 이 때 물리탐사로는 함수비 및 수문학적 모델을 구성하여 실시간 모니터링을 수행할 수 있다(Whiteley et al., 2020; Boyd et al., 2021).

함수비에 가장 효과적인 물리탐사 방법은 전기비저항 탐사로, 활성화된 사면에서 전기비저항 모니터링을 수행 하였는데, 지형정보 및 전극의 변경된 위치 또한 업데이 트하여 사면의 움직임을 시간경과 역산에 완전히 통합하 


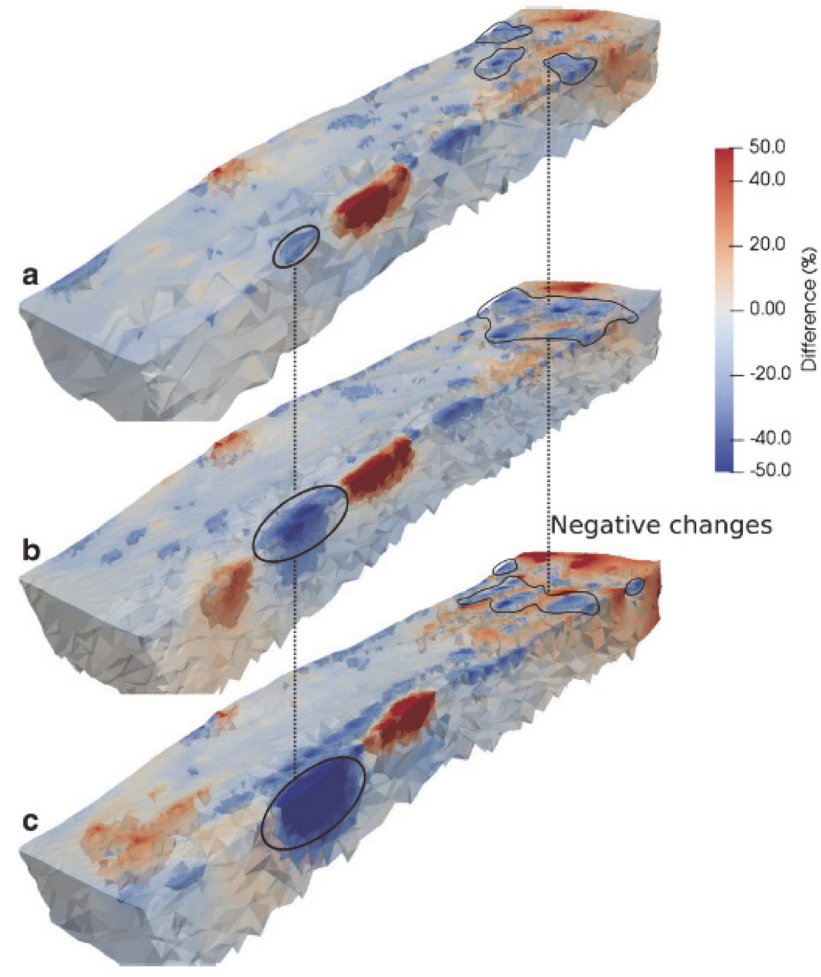

Fig. 7. Comparison of a time-lapse inversion for March 2017 for A) the updated inversion, B) the partially updated inversion and C) the non-updated inversion (Boyd et al., 2021).

여 해석하기도 하였다(Boyd et al., 2021; Fig. 7).

일반적으로 산사태의 장기 모니터링은 보통 수문학적 불안정성을 주로 확인하기 때문에 탄성파 굴절법 탐사는 모니터링에는 사용되지 않는 편이나, 탄성파 굴절법을 이 용한 모니터링을 수행하여 함수량의 변동에 따른 활동면 의 변동을 구성할 수도 있다(Whiteley et al., 2020).

\section{5. 결 론}

국내와 달리 산사태의 특성을 파악하기 위해 물리탐사 방법을 널리 적용하고 있는 국외에서의 사례들을 분석하 여, 사면 안정성 평가를 위한 요소 중 물리탐사를 통해 확인할 수 있는 불안정한 사면물질, 균열 위치 및 연결 성, 지하수위 분포에 초점을 두어 이들의 물성 변화 및 탐사 적용 현황을 정리하였다. 사면 안정성 평가에서 주 로 적용된 물리탐사법들은 전기비저항 탐사와 탄성파 탐 사 위주로 IP 탐사, SP 탐사, GPR 탐사이다.

불안정한 사면물질인 점토질은 다른 매질에 비해 낮은 전기비저항 값과 높은 충전율 값, 낮은 탄성파 속도를 보 이며, 배경 매질들과 비교하여 확연한 물성 차이를 보여 물리탐사를 통한 구별이 용이하다. 균열대에 대한 탐사
의 경우 균열 내의 지하수위 분포에 따라 물성값이 차이 를 보이므로, 전기비저항 탐사, 탄성파 탐사, SP 탐사가 유용하나 균열대가 아닌 균열의 상세한 위치를 파악하기 위해서는 탄성파 반사법, GPR 탐사가 가장 효과적이다. 산사태의 외부적인 요인으로 작용하여 산사태의 발생에 직접적인 영향을 끼치는 지하수에 대한 탐사에 유용한 여러 물리탐사법 중 지하수의 유동을 가장 직접적으로 확인할 수 있는 탐사법은 SP 탐사이다. 특정 시간에서의 사면의 안정성 파악을 위한 탐사도 중요하지만, 산사태 의 위험성은 강우량 혹은 외부적인 요인에 의한 토양 함 수비 변화에 의해 실시간으로 변동하게 되므로 발생 경 보를 내리기 위해서는 모니터링도 중요하다. 이 연구는 향후 산사태 특성화 뿐만 아니라 모니터링을 위한 물리 탐사 적용 연구의 기초를 마련할 수 있을 것으로 판단된다.

\section{사 사}

이 논문은 산업통상자원부의 재원으로 KETEP의 지원 (No. 20194010201920) 및 원자력안전위원회의 재원으로 사용후핵연료관리핵심기술개발사업단 및 한국원자력안전 재단의 지원을 받아 수행된 연구사업(No. 2109092-0121WT112)입니다.

\section{References}

Akpan, S.B., Patrick, I.V., James, S.U. and Agom, D.I. (2015) Determinants of decision and participation of rural youth in agricultural production: a case study of youth in southern region of Nigeria. Russ. J. Agric. Socioecon. Sci., v.43(7), p.35-48.

Archie, G.E. (1942) The electrical resistivity $\log$ as an aid in determining some reservoir characteristics. Transactions of the AIME, v.146(01), p.54-62.

Bogoslovsky, V.A. and Ogilvy, A.A. (1977) Geophysical methods for the investigation of landslides. Geophys., v.42(3), p.562-571. doi: $10.1190 / 1.1440727$

Bortolozo, C.A., Motta, M.F.B., de Andrade, M.R.M., Lavalle, L.V.A., Mendes, R.M., Simões, S.J.C., Mendes, T.S.G. and Pampuch, L.A. (2019) Combined analysis of electrical and electromagnetic methods with geotechnical soundings and soil characterization as applied to a landslide study in Campos do Jordão City, Brazil. J. Appl. Geophy., v.161, p.1-14. doi: 10.1016/ j.jappgeo.2018.11.017

Boyd, J., Chambers, J., Wilkinson, P., Peppa, M., Watlet, A., Kirkham, M., Jones, L., Swift, R., Meldrum, Phil., Uhlemann, S. and Binley, A. (2021) A linked geomorphological and geophysical modelling methodology applied to an active landslide. Landslides, p.1-16. doi: 10.1007/s10346-021-01666-w

Bruno, F. and Martillier, F. (2000) Test of high-resolution seismic reflection and other geophysical techniques on the Boup 
landslide in the Swiss Alps. Surv. Geophys., v.21(4), p.335-350. doi: 10.1023/A:1006736824075

Cardarelli, E. and Di Filippo, G. (2009) Integrated geophysical methods for the characterisation of an archaeological site (Massenzio Basilica-Roman forum, Rome, Italy). J. Appl. Geophy., v.68(4), p.508-521. doi: 10.1016/j.jappgeo.2009.02.009 Cardarelli, E. and Di Filippo, G. (2009) Electrical resistivity and induced polarization tomography in identifying the plume of chlorinated hydrocarbons in sedimentary formation: a case study in Rho (Milan-Italy). Waste. Manag. Res., v.27(6), p.595-602. doi: 10.1177\%2F0734242X09102524

Carson, M.A. and Kirkby, M.J. (1972) Hillslope form and process.

Chambers, J.E., Wilkinson, P.B., Kuras, O., Ford, J.R., Gunn, D.A., Meldrum, P.I., Pennington, C.V.L., Weller., A.L., Hobbs., P.R.N. and Ogilvy, R.D. (2011) Three-dimensional geophysical anatomy of an active landslide in Lias Group mudrocks, Cleveland Basin, UK. Geomorphol., v.125(4), p.472-484. doi: 10.1016/j.geomorph. 2010.09.017

Choi, S.H., Kim, H.S. and Kim, J.S. (2008) IP Characteristics of Sand and Silt for Investigating the Alluvium Aquifer. J. Eng. Geol., v.18(4), p.423-431.

Colombero, C., Baillet, L., Comina, C., Jongmans, D. and Vinciguerra, S. (2017) Characterization of the 3-D fracture setting of an unstable rock mass: From surface and seismic investigations to numerical modeling. Journal of Geophysical Research: Solid Earth, v.122(8), p.6346-6366. doi: 10.1002/2017JB014111

Colombero, C., Comina, C., Umili, G. and Vinciguerra, S. (2016) Multiscale geophysical characterization of an unstable rock mass. Tectonophysics, v.675, p.275-289. doi: 10.1016/j.tecto.2016.02.045

Cruz, GM.B. (2018) Site scale slow moving landslides: characterization by monitoring and modelling (Doctoral dissertation, University of Liverpool).

Dahlin, T., Löfroth, H., Schälin, D. and Suer, P. (2013) Mapping of quick clay using geoelectrical imaging and CPTU-resistivity. Near Surf. Geophys., v.11(6), p.659-670. doi: 10.3997/1873-0604.2013044

de Jesús Arce-Mojica, T., Nehren, U., Sudmeier-Rieux, K., Miranda, P.J. and Anhuf, D. (2019) Nature-based solutions (NbS) for reducing the risk of shallow landslides: Where do we stand?., Int. J. Disaster Risk Reduct., v.41, p.101-293. doi: 10.1016/j.ijdrr. 2019.101293

Deparis, J., Jongmans, D., Cotton, F., Baillet, L., Thouvenot, F. and Hantz, D. (2008) Analysis of rock-fall and rock-fall avalanche seismograms in the French Alps. Bull. Seismol. Soc. Am., v.98(4), p.1781-1796. doi: 10.1785/0120070082

Di Maio, C., De Rosa, J., Vassallo, R., Coviello, R. and Macchia, G. (2020) Hydraulic conductivity and pore water pressures in a clayey landslide: Experimental data. Geosci., v.10(3), p.102. doi: 10.3390/geosciences 10030102

Fatahi, B., Le, T.M., Le, M.Q. and Khabbaz, H. (2013) Soil creep effects on ground lateral deformation and pore water pressure under embankments. Geomech. Geoeng., v.8(2), p.107-124. doi: 10.1080/17486025.2012.727037

Gex, P. (1980) Phénomènes d'électrofiltration liés à quelques sites de barrages.

Gex, P. (1993) Mesures d'électrofiltration sur le glissement de terrain de la Frasse (Préalpes romandes, Suisse). Hydrogéologie (Orléans), (3), p.239-246.

Göktürkler, G., Balkaya, Ç. and Erhan, Z. (2008) Geophysical investigation of a landslide: The Altındağ landslide site, İzmir (western Turkey). J. Appl. Geophy, v.65(2), p.84-96. doi: 10.1016/j.jappgeo.2008.05.008

Haraguchi, K., Li, H.J., Matsuda, K., Takehisa, T. and Elliott, E. (2005) Mechanism of forming organic/inorganic network structures during in-situ free-radical polymerization in PNIPA- clay nanocomposite hydrogels. Macromolecules, v.38(8), p.34823490. doi: 10.1021/ma047431c

Harba, P., Pilecki, Z. and Krawiec, K. (2019) Comparison of MASW and seismic interferometry with use of ambient noise for estimation of S-wave velocity field in landslide subsurface. Acta Geophys., v.67(6), p.1875-1883. doi: 10.1007/s11600-019-00344-9

Heincke, B., Günther, T., Dalsegg, E., Rønning, J.S., Ganerød, G.V. and Elvebakk, H. (2010) Combined three-dimensional electric and seismic tomography study on the Åknes rockslide in western Norway. J. Appl. Geophy., v.70(4), p.292-306. doi: 10.1016/ j.jappgeo.2009.12.004

Jongmans, D. and Garambois, S. (2007) Geophysical investigation of landslides: a review. Bull. Soc. Geol. Fr., v.178(2), p.101-112. doi: 10.2113/gssgfbull.178.2.101

Kamiński, M., Zientara, P. and Krawczyk, M. (2021) Electrical resistivity tomography and digital aerial photogrammetry in the research of the "Bachledzki Hill" active landslide-in Podhale (Poland). Eng. Geol., v.285, p.106004.

Kim, B., Nam, M.J., Jang, H., Jang, H., Son, J.S. and Kim, H.J. (2017) The Principles and Practice of Induced Polarization Method. Geophys. and Geophys. Explor., v.20(2), p.100-113. doi: 10.7582/GGE.2017.20.2.100

Lapenna, V., Lorenzo, P., Perrone, A., Piscitelli, S., Sdao, F. and Rizzo, E. (2003) High-resolution geoelectrical tomographies in the study of Giarrossa landslide (southern Italy). Bull. Eng. Geol. Environ., v.62(3), p.259-268. doi: 10.1007/s10064-002-0184-z

Lee, C.S. (2007), Case study of slop stabilization countermeasure, 2007 Workshop of Engineering Geology, KSEG, p.149-214 (in Korean)

Lee, K.M., Kim, H., Lee, J.H., Seo, Y.S. and Kim, J.S. (2007) Analysis on the Influence of Groundwater Level Changes on Slope Stability using a Seismic Refraction Survey in a Landslide Area. KSEG, v.17(4), p.545-554.

Lévy, C., Baillet, L., Jongmans, D., Mourot, P. and Hantz, D. (2010) Dynamic response of the Chamousset rock column (Western Alps, France). J. Geophys. Res.: Earth Surf., v.115(F4). doi: 10.1029/2009JF001606

Levy, C., Jongmans, D. and Baillet, L. (2011) Analysis of seismic signals recorded on a prone-to-fall rock column (Vercors massif, French Alps). Geophys. J. Int., v.186(1), p.296-310. doi: 10.1111/ j.1365-246X.2011.05046.x

Mainsant, G., Larose, E., Brönnimann, C., Jongmans, D., Michoud, C. and Jaboyedoff, M. (2012) Ambient seismic noise monitoring of a clay landslide: Toward failure prediction. J. Geophys. Res.: Earth Surf., v.117(F1). doi: 10.1029/2011JF002159

Manconi, A. and Giordan, D. (2016) Landslide failure forecast in 
near-real-time. Geomat. Nat. Hazards Risk, v.7(2), p.639-648. doi: 10.1080/19475705.2014.942388

Mandal, B. and Mandal, S. (2018) Analytical hierarchy process (AHP) based landslide susceptibility mapping of Lish river basin of eastern Darjeeling Himalaya, India. Adv. Space Res., v.62(11), p.3114-3132. doi: 10.1016/j.asr.2018.08.008

Marescot, L., Monnet, R. and Chapellier, D. (2008) Resistivity and induced polarization surveys for slope instability studies in the Swiss Alps. Eng. Geol., v.98(1-2), p.18-28. doi: 10.1016/ j.enggeo.2008.01.010

McCann, D.M. and Forster, A. (1990) Reconnaissance geophysical methods in landslide investigations. Eng. Geol., v.29(1), p.59-78. doi: 10.1016/0013-7952(90)90082-C

Meric, O., Garambois, S. and Orengo, Y. (2006, April) Large gravitational movement monitoring using a spontaneous potential network. In 19th EEGS Symposium on the Application of Geophysics to Engineering and Environmental Problems (cp181). Eur. Assoc. Geoscientists \& Engineers. doi: 10.3997/22144609-pdb.181.19

Naudet, V., Lazzari, M., Perrone, A., Loperte, A., Piscitelli, S. and Lapenna, V. (2008) Integrated geophysical and geomorphological approach to investigate the snowmelt-triggered landslide of Bosco Piccolo village (Basilicata, southern Italy). Eng. Geol., v.98(3-4), p.156-167. doi: 10.1016/j.enggeo.2008.02.008

Palis, E., Lebourg, T., Tric, E., Malet, J.P. and Vidal, M. (2017) Long-term monitoring of a large deep-seated landslide (La Clapiere, South-East French Alps): initial study. Landslides, v.14(1), p.155-170. doi: 10.1007/s10346-016-0705-7

Pánek, T., Brázdil, R., Klimeš, J., Smolková, V., Hradecký, J. and Zahradníček, P. (2011) Rainfall-induced landslide event of May 2010 in the eastern part of the Czech Republic. Landslides, v.8(4), p.507-516. doi: 10.1007/s10346-011-0268-6

Patella, D. (1997a) Introduction to ground surface self-potential tomography [Link]. Geophys. Prospect., v.45(4), p.653-681. doi: 10.1046/j.1365-2478.1997.430277.x

Patella, D. (1997b) Self-potential global tomography including topographic effects [Link]. Geophys. Prospect., v.45(5), p.843863. doi: 10.1046/j.1365-2478.1997.570296.x

Patella, D. (1998) Self-potential global tomography including topographic effects (vol 45, pg 843, 1997). Geophys. Prospect., v.46(1), p.103-103. doi: 10.1046/j.1365-2478.1997.570296.x

Pazzi, V., Morelli, S. and Fanti, R. (2019) A review of the advantages and limitations of geophysical investigations in landslide studies. Int. J. Geophys., 2019. doi: 10.1155/2019/2983087

Perrone, A., Iannuzzi, A., Lapenna, V., Lorenzo, P., Piscitelli, S., Rizzo, E. and Sdao, F. (2004) High-resolution electrical imaging of the Varco d'Izzo earthflow (southern Italy). J. Appl. Geophy., v.56(1), p.17-29. doi: 10.1016/j.jappgeo.2004.03.004

Roch, K.H., Chwatal, W. and Brückl, E. (2006) Potentials of monitoring rock fall hazards by GPR: considering as example the results of Salzburg. Landslides, v.3(2), p.87-94. doi: 10.1007/ s10346-005-0026-8

Santoso, B. and Hasanah, M.U. (2019, August) Landslide investigation using self potential method and electrical resistivity tomography (Pasanggrahan, South Sumedang, Indonesia). IOP Conf. Ser.
Earth. Environ. Sci., (Vol. 311, No. 1, 012068). IOP Publishing. doi: 10.1088/1755-1315/311/1/012068

Sass, O. and Krautblatter, M. (2007) Debris flow-dominated and rockfall-dominated talus slopes: Genetic models derived from GPR measurements. Geomorphology, v.86(1-2), p.176-192. doi: 10.1016/j.geomorph.2006.08.012

Sass, O., Bell, R. and Glade, T. (2008) Comparison of GPR, 2D-resistivity and traditional techniques for the subsurface exploration of the Öschingen landslide, Swabian Alb (Germany). Geomorphology, v.93(1-2), p.89-103. doi: 10.1016/j.geomorph.2006.12.019

Schmugge, T.J., Jackson, T.J. and McKim, H.L. (1980) Survey of methods for soil moisture determination. Water Resour. Res., v.16(6), p.961-979. doi: 10.1029/WR016i006p00961

Schmugge, T.J. (1980) Effect of texture on microwave emission from soils: IEEE Geosci. Remote Sens., GE-18, p.353-361. doi: 10.1109/TGRS.1980.350313

Söderblom, R. (1969) Salt in Swedish clays and its importance for quick clay formation. Results from some field and laboratory studies.

Song, S.Y. and Nam, M.J. (2018) A Technical Review on Principles and Practices of Self-potential Method Based on Streaming Potential. Geophys. Geophys-Explor., v.21(4), p.231-243. doi: 10.7582/GGE.2018.21.4.231

Song, S.Y., Cho, A., Kang, P.K. and Nam, M.J. (2021) A Review on Past Cases of Self-potential Surveys for Dikes and Embankments Considering Streaming Potential. J. of Soil and Groundw. Environ., v.26(6), p.1-17. doi: 10.7857/JSGE.2021.26.6.001

Stead, D. and Wolter, A. (2015) A critical review of rock slope failure mechanisms: the importance of structural geology. J. Struct. Geol., v.74, p.1-23. doi: 10.1016/j.jsg.2015.02.002

Sujitapan, C., Kendall, M., Whiteley, J.S., Chambers, J.E. and Uhlemann, S. (2019) Landslide investigation and monitoring using self-potential methods. In 25th EAGE (Vol. 2019, No. 1, p. 1-5). doi: 10.3997/2214-4609.201902428

Tábořík, P., Lenart, J., Blecha, V., Vilhelm, J. and Turský, O. (2017) Geophysical anatomy of counter-slope scarps in sedimentary flysch rocks (Outer Western Carpathians). Geomorphology, v.276, p.59-70. doi: 10.1016/j.geomorph.2016.09.038

Travelletti, J., Demand, J., Jaboyedoff, M. and Marillier, F. (2010) Mass movement characterization using a reflexion and refraction seismic survey with the sloping local base level concept. Geomorphology, v.116(1-2), p.1-10. doi: 10.1016\%2Fj.geomorph. 2009.10.006

Varnes, D.J. (1978) Slope movement types and processes. In: Schuster RL, Krizek RJ (eds) Landslides, analysis and control, special report 176: Transportation research board, National Academy of Sciences, Washington, DC., p.11-33.

Viero, A., Galgaro, A., Morelli, G., Breda, A. and Francese, R.G. (2015) Investigations on the structural setting of a landslideprone slope by means of three-dimensional electrical resistivity tomography. Nat. Hazards, v.78(2), p.1369-1385. doi: 10.1007/ s11069-015-1777-8

Whiteley, J.S., Chambers, J.E., Uhlemann, S., Boyd, J., Cimpoiasu, M.O., Holmes, J.L., Inauen, C.M., Watlet, A., Hawley-Sibbett, L.R., Sufitapan, C., Swift, R.T. and Kendall, J.M. (2020) 
Landslide monitoring using seismic refraction tomography-The importance of incorporating topographic variations. Eng. Geol., v.268, p.105-525. doi: 10.1016/j.enggeo.2020.105525

Zakaria, M.T., Mohd Muztaza, N., Zabidi, H., Salleh, A.N., Mahmud, N., Samsudin, N., Rosli, F.N., Olugbenga, A.T. and Jia, T.Y. (2021) 2-D Cross-Plot Model Analysis Using Integrated Geophysical Methods for Landslides Assessment. Appl. Sci., v.11(2), p.747. doi: 10.3390/app11020747

Kim, W.Y. and Chae, B.G. (2009) Characteristics of Rainfall, Geology and Failure Geometry of the Landslide Areas on Natural Terrains, Korea. KSEG, v.19(3), p.331-344.

Shin, H.O., Kim, M.I. and Yoon, W.J. (2018). Application of geophysical exploration technique to the identification of active weak zones in large scale mountainous region. Geophysics and Geophysical Exploration, v.21(3), p.162-170. doi: 10.7582/ GGE.2018.21.3.162

Lee, M.S., Park, J.H. and Park, Y. (2019) Analysis of Characteristics using Geotechnical Investigation on the Slow-moving Landslides in the Pohang-si Area. J. Korean Soc. For. Sci., v.108(2), p.233240. doi: 10.14578/jkfs.2019.108.2.233

Cho, S.E. (2018) Probabilistic Stability Analysis of Unsaturated Soil Slope under Rainfall Infiltration. J. of the Korean Geotech. Soc., v.34(5), p.37-51. doi: 10.7843/kgs.2018.34.5.37 